\title{
Redescription of Cybaeus abchasicus Charitonov, 1947, with the first description of the male (Aranei: Cybaeidae)
}

\author{
Переописание Cybaeus abchasicus Charitonov, 1947 \\ с первописанием самца (Aranei: Cybaeidae)
}

\author{
Mykola M. Kovblyuk ${ }^{1}$, Aleksandr V. Ponomarev², \\ Konstantin V. Dvadnenko \\ Н.М. Ковбцюк ${ }^{1}$, А.В. Пономарев ${ }^{2}$ К.В. Авадненко ${ }^{2}$
}

\footnotetext{
${ }^{1}$ Zoology Department, National Taurida V.I. Vernadsky University, Yaltinskaya Str. 4, Simferopol 95007, Ukraine. E-mail: kovblyuk@mail.ru ${ }^{2}$ South Scientific Centre RAS, Chekhov Str., 41, Rostov-on-Don 344006 Russia. E-mail: ponomarev1952@mail.ru

${ }^{1}$ Кафедра зоологии Таврического национального университета им. В.И.Вернадского, ул. Ялтинская 4, Симферополь 95007, Украина.

${ }^{2}$ Южный научный центр РАН, пр. Чехова, 41, Ростов-на-Дону 344006 Россия.
}

KEY WORDS: spiders, Cybaeus abchasicus, redescription, Caucasus, Abkhazia, Russia, Krasnodar Province, Adygeya.

КЛЮЧЕВЫЕ СЛОВА: пауки, Cybaeus abchasicus, переописание, Кавказ, Абхазия, Россия, Краснодарский край, Адыгея.

ABSTRACT: Redescription of Cybaeus abchasicus Charitonov, 1947, on the basis of newly collected material is provided. The neotype is designated. Male of this species is described for the first time. Species was previously known from Abkhasia only. It is recorded from Russia for the first time.

РЕЗЮМЕ: По новому материалу приводится иллюстрированное переописание Cybaeus abchasicus Charitonov, 1947. Выделен неотип. Самец описан впервые. Вид был описан из Абхазии, впервые отмечен в России.

\section{Introduction}

Cybaeus L. Koch, 1868, is a genus with 116 described species occurring in Holarctic (only one species is described from Peru) [Platnick, 2010]. Most of species are distributed in the USA and Japan. Eight species are reported from Europe, mainly from the Alps [Maurer, 1992]. Five species are known from Russia, four of them are restricted to the Far East [Platnick, 2010]. Actual diversity of Cybaeus species in the Russian fauna seems to be much higher [Marusik, personal communication].

Two Cybaeus species were reported from Caucasus: C. abchasicus Charitonov, 1947, (from Abkhazia) and C. angustiarum L. Koch, 1868, (from Azerbaijan) [Mikhailov, 1997]. Record of C. angustiarum from Caucasus [Dunin, 1984] probably is misidentification of Paracedicus feti Marusik \& Guseinov, 2003 [cf. Marusik \& Guseinov, 2003]. C. abchasicus was de- scribed on the basis of prosoma of immature female only [Charitonov, 1947]. Brignoli [1978] described the epigyne of a female from Turkey. But it is quite possible that Brignoli's figure [Brignoli, 1978: f. 79] refers to $C$. balkanus Deltshev, 1997 , or to a new species. Male of C. abchasicus remains unknown. Type locality of C. abchasicus is a cave near Gudauta [Charitonov, 1947]. In newly collected material we found the male of C. abchasicus from environs of Gudauta and similar males together with females from the Russian part of Caucasus (Krasnodar Province and Adygeya). So, the aim of this paper is to describe C. abchasicus species on the basis of adult male and female, and to provide new data about its distribution.

\section{Material and Methods}

Specimens for this study are deposited in the following collections: CP - personal collection of A.V. Ponomarev (Rostov-on-Don, Russia); PSU - Department of Zoology of Invertebrate, Perm State University, curator S.L. Esyunin (Perm, Russia); TNU — Zoology Department, V.I. Vernadsky Taurida National University, curator M.M. Kovblyuk (Simferopol, Ukraine); ZMUM - Zoological Museum of the Moscow State University, curator K.G. Mikhailov (Moscow, Russia).

Format of the description follows that of Deltshev [1997]. Coloration was described from specimens preserved in $75 \%$ ethanol/water solution. All measurements are in $\mathrm{mm}$. All scale bars equal to $0.1 \mathrm{~mm}$.

Terms for the copulatory organs used in the text and figures are as follow: $A r$ - anterior reservoir of 


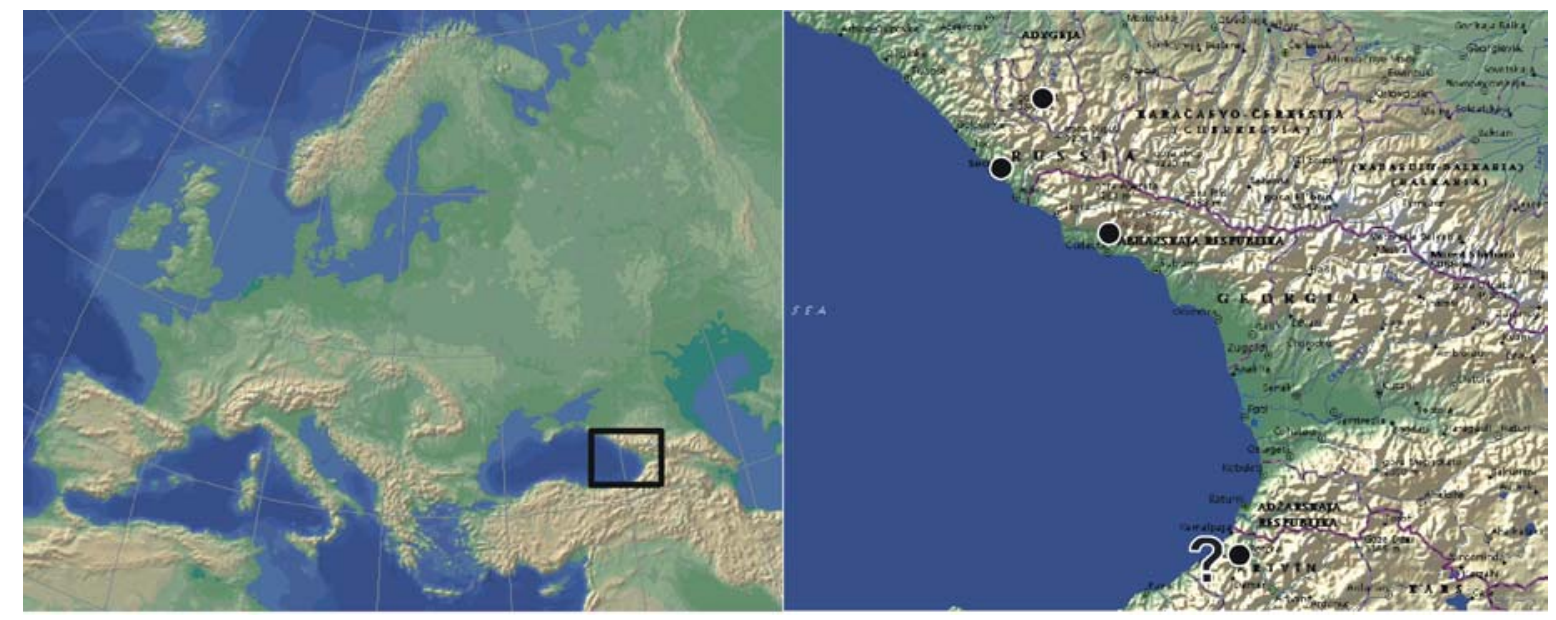

Map 1. Distribution of Cybaeus abchasicus.

Карта 1. Распространение Cybaeus abchasicus.

spermathecae; $C d$ - copulatory duct; $C o$ - copulatory opening; $D l$ - distal lobe of patellar apophysis; $F$ epigynal fovea; $F d$ - fertilization duct; $S$ - strong spine on male palpal tibia; $S e$ - setae on dorso-prolateral side proximal lobe of patellar apophysis; $\mathrm{Pl}-$ proximal lobe of patellar apophysis; $\mathrm{Pr}-$ posterior reservoir of spermathecae.

Illustrations were made using both reflecting and transmitted light microscopes. Photos of epigyne (Figs 14-16) were made after maceration in $\mathrm{KOH} 20 \%$ water solution. Microphotographs were made with EVO40 XVP (LEO 143 OVP) SEM in the South Scientific Centre RAS, Rostov-on-Don, Russia.

\section{Description}

\section{Cybaeus abchasicus Charitonov, 1947}

Figs 1-17.

C. a. Charitonov, 1947: 18-9, f. 2 (juv. + ; holotype in the PSU, lost and not examined; $\sigma^{7}$ neotype designated here, deposited in ZMUM).

C. a.: Brignoli, 1978: 508, f. 79 (†).

PREVIOUS RECORDS. Abkhazia (Gudauta Distr.: Tarkiladze Cave) [Charitonov, 1947; Dzhanashvilli, 1965]; Turkey (near Artvin: Borcka Vil.) [Brignoli, 1978].

MATERIAL. RUSSIA. Krasnodar Prov.: $1 \sigma^{7}$ (ZMUM; neotype, designated here), env. Sochi, Bzych Mt., $650 \mathrm{~m}$ a.s.1., forest, 11-19.07.2002, leg. P. Laguta. $2 \sigma^{\top} \sigma^{\top}, 1$ ㅇ (TNU), same place, 1119.07.2002, leg. P. Laguta. Adygeya Republic: $4 \sigma^{7} \sigma^{7}$ (TNU), Caucasian Reserve, env. kordon Guzeripl, 435' $\mathrm{N}, 40^{\circ} 09^{\prime} \mathrm{E}, 985$ m a.s.1., forest, pitfalls, 16-23.08.2009, leg. M.M. Kovblyuk; 32 $\sigma^{7} \sigma^{7}, 10$ 우 (CP-44.10.1/3), Caucasian Reserve, Pastbishche Abago Mt. range, $1750 \mathrm{~m}$ a.s.1., forest with Acer, pitfalls, 2.07-29.09. 2009, leg. Yu.A. Chumachenko; $60 \sigma^{\top} \sigma^{\top}, 1$ (CP-44.10.1/4), Caucasian Reserve, env. kordon Guzeripl, $1000 \mathrm{~m}$ a.s.l., fores with Fagus, Abies, pitfalls, 8.07-12.09.2009, leg. Yu.A. Chumachenko; $148 \sigma^{\top} \sigma^{\top}, 23$ 우 (CP-44.10.1/5), same locality, pitfalls, 23.06-13.10.2009, leg. Yu.A. Chumachenko. ABKHAZIA. 1 o (ZMUM, possibly lost), Gudauta Distr., $50 \mathrm{~km} \mathrm{~N}$ Gudauta, $30 \mathrm{~km} \mathrm{~N}$ from Achandara Vil., Gunarkhva, 12-14.08.2004, leg. P.P. Ivliev.

DIAGNOSIS. C. abchasicus is closely related to $C$. balkanus, but differs by having eight posterior cheli- ceral teeth (six in C. balkanus). Males differ also by the presence of spines on the distal lobe $(D l)$ of patellar apophysis and 2-3 long setae on the dorso-prolateral side of the proximal lobe $(P l)$ (both are lacking in $C$. balkanus [cf. Deltshev, 1997: f. 5-6]). Epigyne of $C$. abchasicus slightly differ from $C$. balkanus [see Deltshev, 1997: f. 7-9]) by larger anterior reservoirs $(A r)$ and relatively smaller copulatory duct $(C d)$.

C. abchasicus differs from C. angustiarum [cf. Blauwe, 1973: f. 9-11] and from the generotype, C. tetricus (C.L. Koch, 1839) [cf. Nentwig et al., 2006] by the shape of the patellar apophysis (lacking proximal lobe in C. angustiarum and C. tetricus) and by the internal structure of epigyne.

DESCRIPTION. Measurements of male / female. Total length 7.0 / 7.3. Carapace 3.5 / 3.8 long, 2.4 / ? wide (carapace of female is deformed); abdomen 3.3 / 3.5 long; sternum $1.7 / 1.6$ long and 1.5 / 1.5 wide. Carapace is similar in both sexes, brown with pattern as in Charitonov's drawing [Charitonov, 1947: f. 2]. Abdomen gray with pattern of 3-4 pairs of white marks, or uniformly colored without pattern. Chelicerae in both sexes dark brown, anterior / posterior margin with 3 / 8 teeth. Distal teeth larger than proximal teeth (Fig. 17). Legs brown, femora annulated. Femur I 2.9 / 2.9 long.

Male palp as in Figs 1-3, 6-13; patella with very characteristic apophysis with two lobes - distal pearshaped $(D l)$ and proximal $(P l)$. Both lobes covered with short and stout dark spines, numerous in proximal lobe (25-30 spines), but rare in distal lobe (5-8 spines). Distal end of patella with one short, very strong, thick spine $(S)$. Tibia with characteristic lateral furrow.

Epigyne and vulva as in Figs 4-5, 14-16. Epigyne with two pairs of reservoirs ( $A r$ and $P r$ ) and with copulatory duct $(C d)$ between them. Copulatory ducts open in copulatory openings $(\mathrm{Co})$ in anterior corners of triangular epigynal fovea $(F)$.

DISTRIBUTION. Mountainous forests on the eastern Black Sea coast: north to Sochi and Adygeya (Rus- 

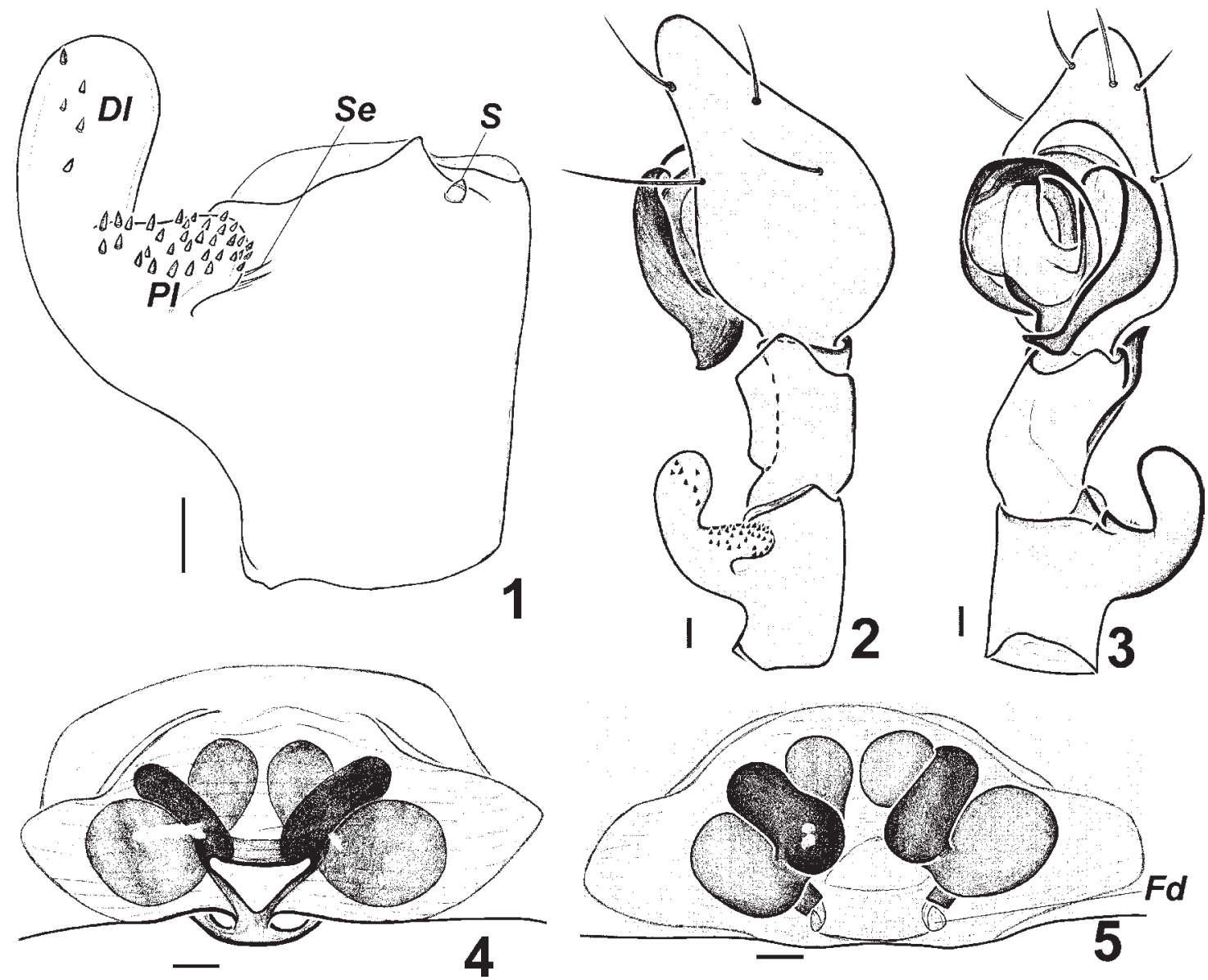

Figs 1-5. Copulatory organs of Cybaeus abchasicus: 1 - patella of male palp, dorsal-retrolateral view; 2 - male palp, retrolateral view; 3 - male palp, ventral view; 4 - epigyne, ventral view; 5 - epigyne, dorsal view.

Рис. 1-5. Копулятивные органы Cybaeus abchasicus: 1 - колено пальпы самца, дорсо-ретролатерально; 2 - пальпа самца, ретролатерально; 3 - пальпа самца, вентрально; 4 - эпигина, вентрально; 5 - эпигина, дорсально.

sia), south to Artvin (Turkey) (Map 1) [Charitonov, 1947; Brignoli, 1978; present data].

NOTE. C. abchasicus was described on the basis of prosoma of immature female only [Charitonov, 1947]. Collection of D.E. Kharitonov is deposited in PSU. Since only leg IV, tarsi I and III and chelicera are found in collection [S.L. Esyunin, personal communication, 26.VII.2010], the male collected near the type locality (environs of Sochi, Bzych Mt.) was designated as the neotype (deposited in ZMUM) in order to stabilize the taxonomic status of this species.

The presence of another species, C. angustiarum, in Caucasus is doubtful. Record of $C$. angustiarum by Dunin [1984] seems a misidentification of Paracedicus feti [cf. Marusik \& Guseinov, 2003: 33].

It is considered that $C$. abchasicus is the easternmost species of the genus Cybaeus in the West Palaearctic. Cybaeus has clear disjunction - between the West Caucasus and the Far East of Asia.

ACKNOWLEDGEMENTS. The authors are very thankful to D.G. Matishov, Director of Institute of Arid Zones,
South Scientific Centre RAS, Corresponding Member of RAS (Rostov-on-Don), for the possibility to use SEM and other equipment. The authors sincerely thank Yu.A. Chumachenko (Maykop, Russia), P.P. Ivliev (Rostov-on-Don, Russia) and E.V. Prokopenko (Donetsk, Ukaraine), who collected and provided us the specimens of spiders, and to G.M. and A.G. Fedorenko (both - South Scientific Centre, Rostov-on-Don) for the help with making SEM photographs. The authors sincerely thank T. Blick (Hummeltal, Germany), Yu.M. Marusik (Magadan, Russia) and K.G. Mikhailov (Moscow, Russia) for their great help in the search of the relevant references. M.K. provides many thanks to N.B. Eskin and Yu.A. Chumachenko (both from Maykop) for making possible the collecting expedition to Caucasian State Nature Biosphere Reserve in 2009. We especially appreciate the efforts of S.L. Esyunin (Perm), who kindly searched for the holotype of $C$. abchasicus in the collection PSU and informed us that it is lost. We thank P.E. Gol'din (Simferopol) for improving the English of the earlier draft and Yu.M. Marusik for some important remarks and corrections. English of the final draft was checked by Robin Leech (Edmonton, Canada). 


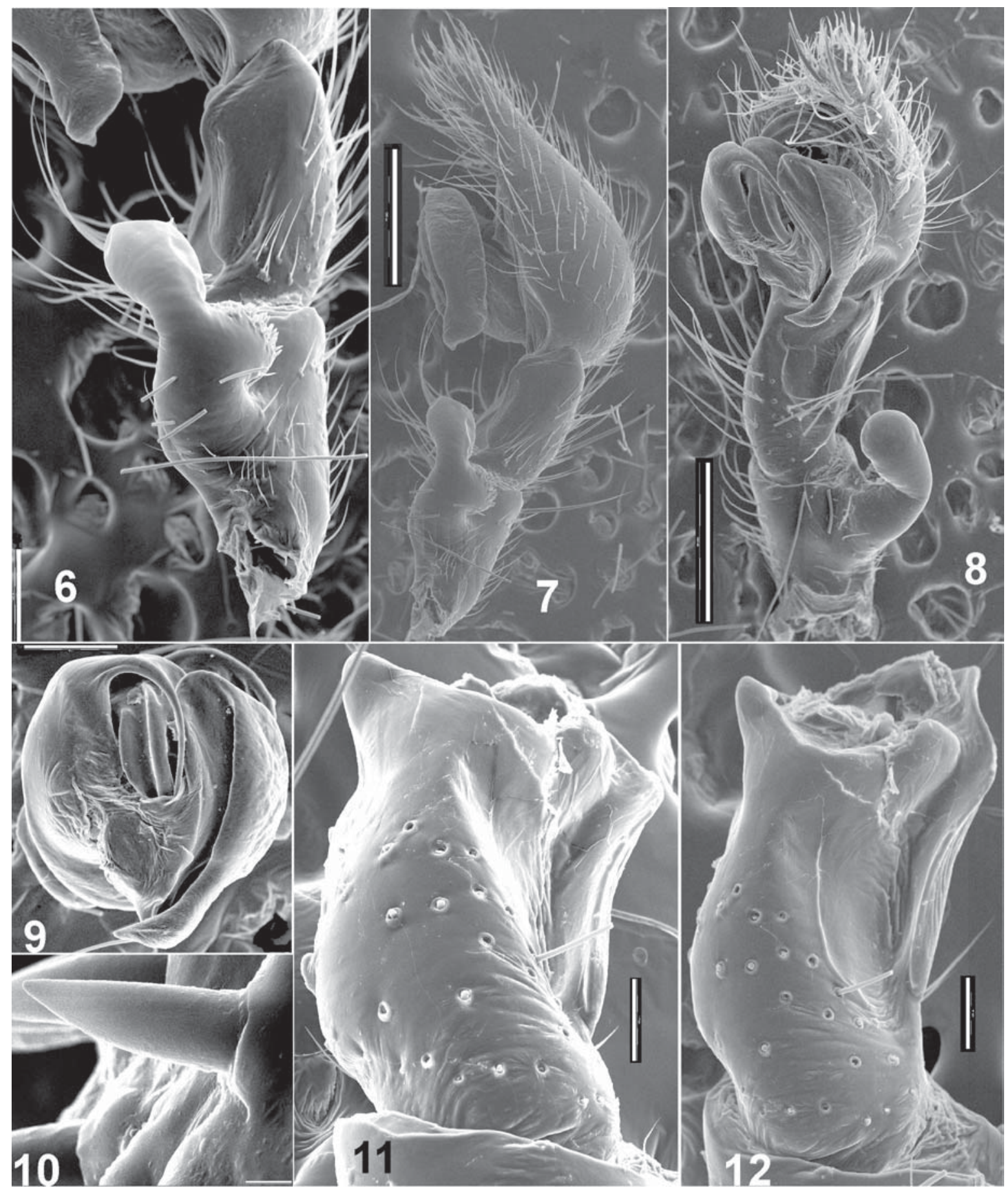

Figs. 6-12. Male palp of Cybaeus abchasicus: 6 - patella and tibia of palp, retrolateral view; 7 - palp, retrolateral view; 8 - palp, ventral view; 9 - bulbus, ventral view; $10-$ patellar spine; 11 - tibia of palp, prolateral-caudal view; $12-$ tibia of palp, ventralprolateral view.

Figs. 6-12. Пальпа самца Cybaeus abchasicus: 6 - колено и голень пальпы, ретролатерально; 7 - пальпа, ретролатерально; 8 пальпа, вентрально; 9 - бульбус, вентрально; 10 - шип с колена пальпы; 11 - голень пальпы, пролатерально-сзади; 12 голень пальпы, вентро-пролатерально. 


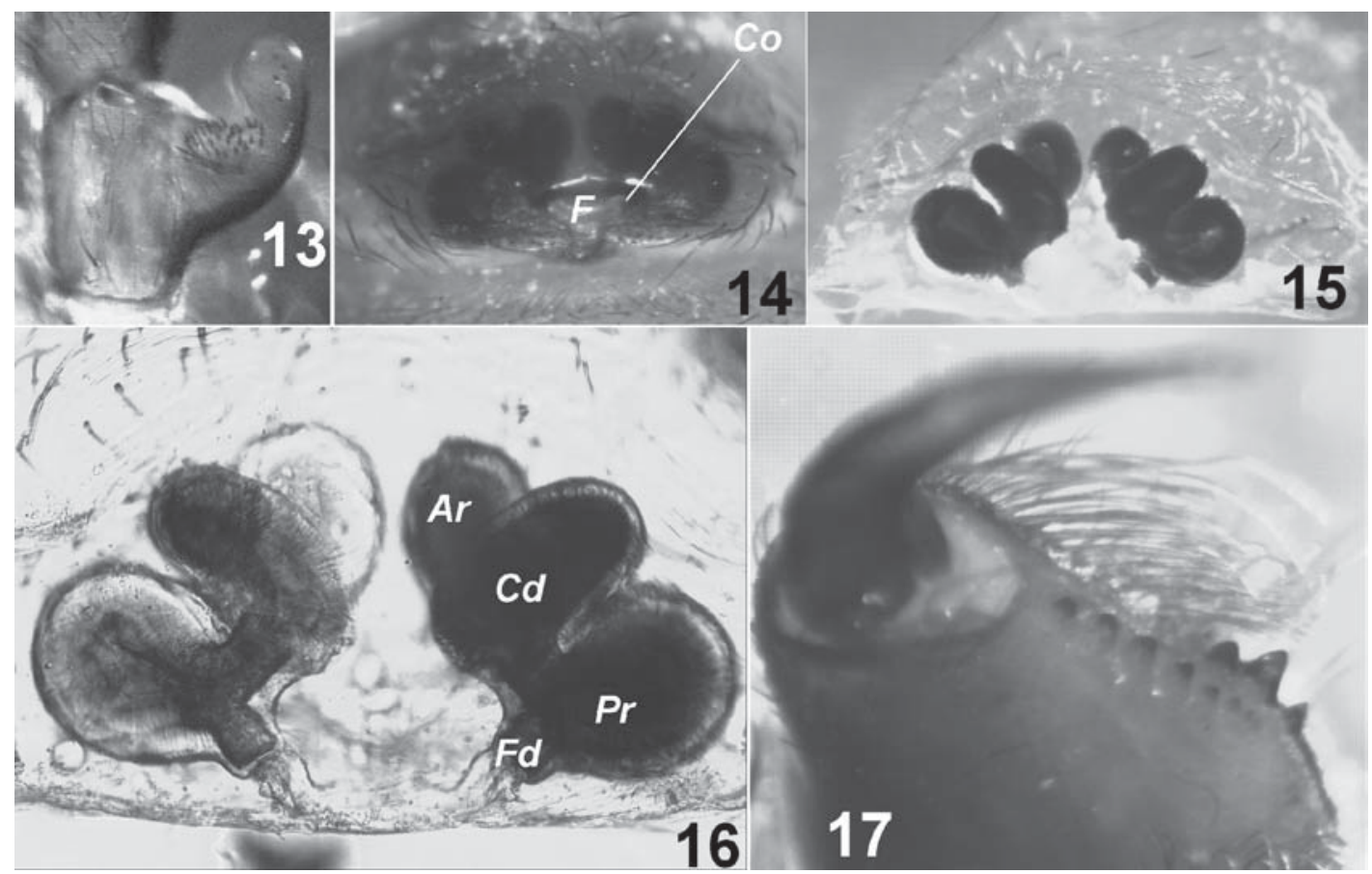

Figs 13-17. Copulatory organs of Cybaeus abchasicus: 13 - patella of male palp, dorsal-retrolateral view; 14 - epigyne, ventral view; 15 - epigyne, dorsal view; 16 - epigyne, dorsal view (after maceration); 17 - female chelicerae, posterior view.

Рис. 13-17. Копулятивные органы Cybaeus abchasicus: 13 - колено пальпы самца, дорсо-ретролатерально; 14 - эпигина, вентрально; 15 - эпигина, дорсально; 16 - эпигина, дорсально; 17 - хелицера самки, сзади.

This work was supported in part by the Russian Foundation of Basic Research (grant \# 09-04-90900 - моб._снг_ст.) and the Karadagh Nature Reserve.

\section{References}

Blauwe R. 1973. Revision de la famille des Agelenidae (Araneae) de la region Mediterraneenne // Bull. Inst. r. Sci. nat. Belg. T.49. No.2. P.1-111.

Brignoli P.M. 1978. Ragni di Turchia V. Specie nuove o interessanti, cavernicole ed epigee, di verie famiglie (Araneae) // Revue suisse Zool. T.85. Fasc.3. P.461-541.

Charitonov D.E. 1947. [Spiders and harvestmen from the caves of the Black Sea Coast of the Caucasus] // Byulleten' Moskovsk. Obshchestva Ispytatelei Prirody. T.52. No.2. P.15-28 [in Russian with English summary].

Deltshev Ch. 1997. A new species of Cybaeidae: Cybaeus balkanus spec. nov. from the mountains of Balkan peninsula (Arachnida: Araneae) // Reichenbachia. Bd.32. Nr.1. P.1-4.

Dunin P.M. 1984. [Fauna and ecology of the spiders of the Apsheron Peninsula, Azerbaijan SSR] // Fauna i ekologiya paukoobraznykh. Perm: Perm State Univ. P.45-60 [in Russian].
Dzhanashvili R.A. 1965. [Some data on the cavernicolous fauna of Georgia] // Sbornik speleologicheskoy komissii "Peschery Gruzii”. Akademia nauk Gruzinskoy SSR. T.3. P.21-24. [in Russian].

Marusik Yu.M., Guseinov E.F. 2003. Spiders (Arachnida: Aranei) of Azerbaijan. 1. New family and genus records // Arthropoda Selecta. Vol.12. No.1. P.29-46.

Maurer R. 1992. Zur Gattung Cybaeus im Alpenraum (Araneae: Agelenidae, Cybaeinae) - Beschreibung von C. montanus n. sp. und $C$. intermedius n. sp. // Revue suisse Zool. T.99. Fasc.1. P.147-162.

Mikhailov K.G. 1997. Catalogue of the spiders of the territories of the former Soviet Union (Arachnida, Aranei). Moscow: Zoological Museum of the Moscow State University. 416 pp.

Nentwig W., Hanggi A., Kropf C., Blick T. 2006. Central European spiders - determination key. At: www.araneae.unibe.ch/ Bestimmung/english/Familienschluessel_eng_Ganz.htm

Platnick N.I. 2010. The world spider catalog, version 10.5. American Museum of Natural History, online at http://research.amnh. org/entomology/spiders/catalog/index.html

Responsible editor Yu. Marusik 